\title{
MECHANICAL AND TRADITIONAL HARVESTING METHODS FOR WHEAT CROP
}

\section{A.I. Moussa*}

\section{ABSTRACT}

Three combine harvesters at different service life (Fortschritt E514 \{1\} has been serving for 25 years - Class \{2\} has been serving for 15 years and John Deer \{3\} has been serving for 2 years) were tested and compared to another mechanical method mower than thresher (one thresher has free knives on the threshing drum $\{1\}$ and the other has fixed knives on the drum \{2\}) compared to traditional method (sickle than thresher \{1\}). The mechanical harvesting methods were done at three different field speeds 1.9, 2.7 and $3.9 \mathrm{~km} / \mathrm{h}$ for mower and combines. Also, three different moisture contents 12.1, 14.34 and $16.58 \%$ were effected on harvesting, threshing unthreshing, damaged grain and total grain losses for the previous machines.

The experimental results showed that pre-harvesting losses for Sakha 93 was about $0.51 \%$. The highest total grain losses for combine 1, 2, 3 and mower were 10.36, 7.19. 3.14 and $3.98 \%$ respectively at field speed 3.9 $\mathrm{km} / \mathrm{h}$ and grain moisture content $12.1 \%$. Besides, the highest sickle loss is $2.01 \%$ at moisture content $12.1 \%$. The highest un-threshing losses were 1.13 and $1.22 \%$ for thresher 1 and 2 respectively at grain moisture content $16.58 \%$. The highest grain damage were 2.24 and $2.02 \%$ at grain moisture content $12.1 \%$ for thresher 1 and 2 respectively. Harvesting speed $2.7 \mathrm{~km} / \mathrm{h}$ gave the lowest energy with combine 1, 2 and 3 , which were 38.95, 34.76 and $43.61 \mathrm{~kW}$.h/fed respectively. Mechanical method (mower then thresher) consumed about double energy consumed by combine; while, traditional method (sickle then thresher) consume about the same energy with combine. Thresher 2 consumed less energy than thresher 1 that because thresher 2 has free knives on the drum depend on the impact. The highest criterion cost with combine1, 2, 3 and mower are 355.9, 277.59, 177.56 and 158.06 LE/fed respectively at field speed $3.9 \mathrm{~km} / \mathrm{h}$, and grain moisture content $12.1 \%$.

* Senior Res ., Ag. Eng. Res. Inst . ( AEn.RI), Egypt . 
The highest criterion cost with sickle is 229.65 LE/fed at grain moisture content $12.1 \%$. The highest criterion cost with thresher 1 and 2 are 225.89 and $223.67 \mathrm{LE} /$ fed respectively at grain moisture content $12.1 \%$.

\section{INTRODUCTION}

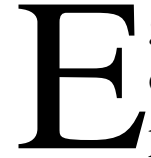

gyptian agricultural policy aimed to increase wheat yield not only by increasing cultivated area but also by increasing productivity per unit area. Issakhan et, al. (2005) stated that wheat has a prominent position among all grain in the world and as the most important cereal grain in Egypt. While it is the cheapest and most stable source of proteins and calories in most East countries its average consumption can supply up to 30 to $40 \%$ of human energy and protein requirements respectively. Hassen et al (1994) found that total grain losses and criterion cost for combine were minimum and performance efficiency was maximum under the following conditions:

1- Forward speed of $2.1 \mathrm{~km} / \mathrm{h}$

3- Cylinder speed of $2.5 \mathrm{~m} / \mathrm{s}$

5- Straw walker speed of $0.12 \mathrm{~m} / \mathrm{s}$

7- Grain moisture content of $12.5 \%$
2- Cutter-bar speed of $1.2 \mathrm{~m} / \mathrm{s}$

4- Front concave clearance of $9 \mathrm{~mm}$

6- Shoe speed of $0.5 \mathrm{~m} / \mathrm{s}$

Increasing forward speed from 2.1 to $3.9 \mathrm{Km} / \mathrm{h}$ at a constant cutter bar speed of $1.2 \mathrm{~m} / \mathrm{s}$ and constant grain moisture content of $19.2 \%$ increased header losses from 0.82 to $1.3 \%$ from 0.72 to $1.09 \%$ and from 0.22 to 0.87 when using yanmar, Deutz and Fortshritt combines for wheat crop. Kassem (1995) stated that the effect of some crop and machine parameters on wheat and barely harvesting losses in Saudi Arabia. He reported that cutter bar losses increased from 1.1 to $2.1 \%$ as the field speed increased from 1 to $5 \mathrm{Km} / \mathrm{h}$. Abd El-Moawla (1996) studied that combine harvesters have been developed to increase the combine capability in combining certain crops, to overcome hard conditions of crops to facilitate easier maintenance and to increase the overall efficiency of the combine. Wange et al. (1988) illustrated that at harvesting barely and wheat the separation loss was lower than $1 \%$ for the test combine at material other than grain feed rate below $8 \mathrm{Mg} / \mathrm{h}$. But when the feed rate increased to a certain level the loss increased drastically. The ASAE Standard (1996) contains a list of machine efficiencies and range of traveling speeds. For combine harvesters, values 
of efficiencies in the range of 65-85 percent are usually obtained for machines operating speeds ranging between $3.34-6.68 \mathrm{Km} / \mathrm{h}$. These yield effective field capacities ranging from 0.55 to 1.4 fed./h per meter width of the machine. Awady et al (1982) stated that the criterion cost of comparing different harvesting methods includes operating cost, losses evaluated at the current market price. The minimum criterion cost includes the most economical method.

The objectives of this research were to evaluate different combine harvesters at different service life comparing with mechanical method (mower then thresher) and traditional method (sickle then thresher) in addition to, studying the performance of two different geometrical designs for thresher drum with respect to grain losses, energy and cost.

\section{MATERIAL AND METHODS}

The experiments were conducted at Nubaria site during summer season 2007 for harvesting wheat crop Sakha 93. Three combine harvesters at different service life (Fortschritt E514 has been serving for 25 years Class has been serving for 15 years and John Deer has been serving for 2 years) were tested and compared to another mechanical system mower then thresher (one thresher has free knives fixed on the threshing drum and the other has fixed knives on the drum) compared also with traditional method (sickle than thresher). Table (1). summarized some technical specifications on the utilized tractor, combines, mower and threshers.

Standard measuring instruments were used to measure, length of plants number of grains/panicle, number of panicle $/ \mathrm{m}^{2}$ and weight of 1000 grain.

\section{Electric oven:}

To determine the grain and straw moisture contents, an electric oven was used according to the ASAE standard $1998 ; 130^{\circ} \mathrm{C}$ for one hour.

\section{Electric balance:}

An electric balance model XT 4200C has maximum weight $4200 \mathrm{gm}$ and minimum weight $0.5 \mathrm{gm}$ was used to measure weight of samples. 


\section{Experimental Design:}

Randomization Complete Block Design (RCBD) was used to determine the optimum values of three forward speeds, three moisture content and three harvesting systems. Each value was repeated three times.

Table 1. Some technical data of machines

\begin{tabular}{|l|l|}
\hline Tractor & Nasr 48.5 kW \\
\hline Combine 1 & Fortschritt E514, cutting width $4.2 \mathrm{~m}$ \\
\hline Combine 2 & Class 3 m cutting width \\
\hline Combine 3 & John Deer 155 WTS, cutting width $6.2 \mathrm{~m}$ \\
\hline Mower & Gasbardo, Single knife $100 \mathrm{~cm}$ width \\
\hline Thresher 1 & $\begin{array}{l}\text { Gabr drum diameter } 74 \mathrm{~cm} \text { and length } 120 \mathrm{~cm} \text {. Number of } \\
\text { beater 4, concave width } 80 \mathrm{~cm} \text {, number of holes in } 100 \mathrm{~cm}^{2} 14 . \\
\text { Free knives fixed on 4 rows }\end{array}$ \\
\hline Thresher 2 & $\begin{array}{l}\text { Shams drum diameter } 72 \mathrm{~cm} \text { and length } 120 \mathrm{~cm} . \text { Number of } \\
\text { beater 4, concave width } 80 \mathrm{~cm} \text {, number of holes in } 100 \mathrm{~cm}^{2} 14 \\
\text { Fixed knives on 4 row }\end{array}$ \\
\hline
\end{tabular}

\section{Forward speed:}

Forward speed was determined by measuring the time consumed for distance of 30 meter of rear tractor wheels and combine.

$$
\mathrm{S}=\mathrm{d} / \mathrm{t}
$$

$\mathrm{S}=$ forward speed, $\mathrm{m} / \mathrm{s}$

$$
\mathrm{t}=\text { traveling time, sec }
$$

$\mathrm{d}=$ traveling distance, $\mathrm{m}$

\section{Germination:}

Germination was calculated by the following equation:

$$
G=\frac{P}{d} \times 100, \%
$$

Where:

$\mathrm{P}=$ Average number of plants $\quad \mathrm{d}=$ Average number of seeds

\section{Harvesting methods:}

Three different harvesting methods have been considered in this study:

1- Three combines at different service life 25, 15 and 2 years where compared with each other (they have the same threshing system)

2- Mower then thresher

Two different threshers with different geometrical design, one has free knives fixed on the threshing drum and the other has fixed knives fixed on the threshing drum in four rows 
3- Sickle then thresher (traditional methods)

The previous mechanical methods were compared with traditional one.

\section{Test procedure of harvesting losses:}

\section{Pre-harvesting loss:}

Select unharvested area of the field well in from the edges. Place a frame 1 square meter in the standing crop to evaluate weight of grains laying on the ground within the frame.

$$
\operatorname{Pr} e-\text { harvestingloss }=\frac{\text { Grains on the ground beforeharvesting }}{\text { Total yield }} \times 100, \%
$$

\section{Sickle, mower and combine header losses:}

After baking the length of the machine, place the one-square-meter measuring frame on the ground in the front of the machine within the harvested area. Count the number of kernels found in the frame. Several other samples area have been checked and average of kernels was count. Subtract the number of kernels found in the pre-harvest loss.

$$
\text { Harvestingloss }=\frac{H}{T} \times 100, \%
$$

Where:

$\mathrm{H}=$ Sickle, mower or combine header losses weight, $\mathrm{kg} / \mathrm{m}^{2}$

$\mathrm{T}=$ Total grain yield, $\mathrm{kg} / \mathrm{m}^{2}$

\section{Drum straw walker and shoe losses for combine harvester:}

Role of screen was hold behind combine to receive all material falling during harvesting operation. After the combine was moving for the distance of 10 meter (length of the screen), the grains on the screen were separated and weighed. Replications were done for the test. Drum, straw walker and cleaning losses were calculated using the following equation

$$
(D+S w+C) \text { losses }=\frac{D+S w+C}{T} \times 100, \%
$$

Where:

$\mathrm{D}=$ drum losses, $\mathrm{kg} / \mathrm{m}^{2} \quad \mathrm{Sw}=$ straw walker losses, $\mathrm{kg} / \mathrm{m}^{2}$

$\mathrm{C}=$ cleaning losses, $\mathrm{kg} / \mathrm{m}^{2} \quad \mathrm{~T}=$ total grain yield, $\mathrm{kg} / \mathrm{m}^{2}$

\section{Thresher losses:}

Thresher losses included damaged and unthreshed grains were calculated as follow: 


$$
\begin{gathered}
\text { Grain damage }=\frac{\text { Mass of grain damage }}{\text { Total mass of grains }} \times 100, \% \\
\text { Un-threshed grains }=\frac{\text { Mass of unthreshed grains }}{\text { Total mass of grains }} \times 100, \%
\end{gathered}
$$

Total grain losses $=$ damaged grains + un-threshed grains

\section{Actual field capacity ( A.F.C):}

Field capacity was measured for each case by recording the operating time for combines and mower, ignoring transportation time. Also, feed rate one ton $/ \mathrm{h}$ has been recorded for threshers.

$$
\text { Actual field apacity }=\frac{1}{\text { Total time in hours required per fed. }} \quad,(\text { fed./ h) }
$$

\section{Fuel consumption:}

Fuel consumption per unit time was determined by measuring the volume of fuel consumed during each operation.

\section{Determination of the power requirement:}

The following formula was used to estimate Power (P) Embaby, (1985):

$$
\mathrm{P}=(\mathrm{Fc} / 3600) \times \rho \times \text { L.c.v } \times 427 \times \eta_{\text {th }} \times \eta_{\mathrm{m}} \times(1 / 75) \times(1 / 1.36), \mathrm{kW}
$$

Where:

$$
\begin{array}{ll}
\mathrm{Fc}=\text { Fuel consumption, } & \mathrm{L} / \mathrm{h} \\
\rho=\text { Density of fuel }, & \mathrm{kg} / \mathrm{L}(0.85 \mathrm{~kg} / \mathrm{L} \text { for diesel fuel }) \\
\mathrm{L} . \mathrm{c} . \mathrm{V}=\text { Lower calorific value }, & \mathrm{kCal} / \mathrm{kg}(10000 \text { for diesel fuel }) \\
427=\text { thermo-mechanical equivalent }, \quad \mathrm{kg} . \mathrm{m} / \mathrm{kCal} . \\
\eta_{\mathrm{th}}=\text { Thermal efficiency of the engine }(40 \% \text { for diesel engine }) \\
\eta_{\mathrm{m}}=\text { Mechanical efficiency of the engine }(80 \% \text { for diesel engine })
\end{array}
$$

\section{Energy requirements:}

The following formula was used to calculate the energy requirements for combines and mower:

$$
\text { Energy requirement }=\frac{\text { Power }, k W}{\text { Actual field capacity, fed./ } h} \quad, k W . h / f e d
$$

The following formula was used to calculate the energy requirements for threshers.

$$
\text { Energy requirement }=\frac{\text { Power }, k W}{\text { Feed rate }, M g / h} \quad, k W . h / \text { fed }
$$


The human energy expenditure involved in the field operations can be estimated as a normal and healthy human labor supplies $0.1 \mathrm{hp}$ (Chancellor, 1981).

Human energy $(\mathrm{kW})=0.1 \times 0.746 \times$ number of labors

\section{Yield:}

Yield was recorded as a final target for harvesting operation. Three random samples were taken for each experimental plot. Aluminum square frame $1 \times 1 \mathrm{~m}$ has been made as a sampler to determine yield per feddan (weight of kernels $/ \mathrm{m}^{2}$ ).

\section{Harvesting cost:}

The cost of performing the different operations was estimated considering the conventional way of estimating both fixed and variable costs: The value of grain losses for each different variety has been considered at the different field speeds and grain moisture contents; besides, the operating cost for combines and mower was calculated by the following equation.

$$
\text { Operating } \cos t=\frac{\text { Machine } \cos t, \text { L.E. } / \mathrm{h}}{\text { Actual field capacity, fed./ } h} \quad \text {, L.E./ fed }
$$

The operating cost for threshers was calculated by the following equation.

$$
\text { Operating } \cos t=\frac{\text { Machine } \cos t, \text { L.E. } / h}{\text { Feed rate, } M g / h} \quad \text { L.E./ Mg }
$$

The criterion cost $=$ Operating cost + Value of grain losses, L.E./ Mg

\section{RESULTS AND DISCUSSION}

\section{Crop characteristics}

Some crop characteristics are tabulated in table 2 . The average value of germination is $89.89 \%$.

Table 2. Mean values of crop characteristics of wheat crop.

\begin{tabular}{|l|c|}
\hline plant height, Cm & 108.85 \\
No. of grain $/$ panicle & 51 \\
No. of panicles $/ \mathrm{m}^{2}$ & 380 \\
weight of 1000 grain, gm & 46.75 \\
yield, Mg/fed. & 2.47 \\
\hline
\end{tabular}




\section{Pre-harvesting loss:}

Pre-harvesting loss decreased by increasing moisture contents (w.b). grain moisture content and straw moisture content were also affected by daily hours table 3 .

Table 3. Pre-harvesting loss as affected by daily time and moisture content.

\begin{tabular}{|c|c|c|c|}
\hline $\begin{array}{c}\text { Daily } \\
\text { time }\end{array}$ & $\begin{array}{c}\text { Grains moisture } \\
\text { content, } \%\end{array}$ & $\begin{array}{c}\text { Straw moisture } \\
\text { content, } \%\end{array}$ & $\begin{array}{c}\text { Pre-harvesting } \\
\text { loss, } \%\end{array}$ \\
\hline $9^{\mathrm{AM}}$ & 16.58 & 32.3 & 0.38 \\
\hline $12^{\mathrm{PM}}$ & 12.1 & 26.71 & 0.76 \\
\hline $4^{\mathrm{PM}}$ & 14.34 & 31.01 & 0.51 \\
\hline
\end{tabular}

\section{Manual loss:}

Traditional method of harvesting and threshing requires four important operations: harvesting, transporting, threshing and winnowing the grain. Grain loss using sickle was measured and tabulated in table 4. The highest manual harvesting loss is $2.01 \%$ at moisture content $12.1 \%$, while the lowest manual loss is $1.33 \%$ at moisture content $16.58 \%$. Plants were collected next to thresher.

The highest amount of losses was in the transportation stage as seen in the following table

Table 4. Grain loss for sickle at different daily moisture contents

\begin{tabular}{|c|c|c|}
\hline Moisture content, $\%$ & Manual loss, $\%$ & Transportation loss, \% \\
\hline 12.1 & 2.01 & 11.32 \\
\hline 14.34 & 1.67 & 10.81 \\
\hline 16.58 & 1.33 & 10.52 \\
\hline
\end{tabular}

\section{Mechanical harvesting losses:}

\section{Combine header and mower losses:}

The results of grain harvesting losses for the tested mower and each combine header at three harvesting speeds of 1.9, 2.7 and $3.9 \mathrm{~km} / \mathrm{h}$ were recorded and compared with manual harvesting using sickle. It is clear from Fig (1) that mower and combine header 1, 2 and 3 increase losses with the increase of harvesting speed. The highest header losses for combine 1, 2, 3 and mower were, 5.15, 3.27, 1.19 and 3.98\% respectively at forward speed $3.9 \mathrm{~km} / \mathrm{h}$ and grain moisture contents 12.1 $\%$. This may be due to the system of gathering, cutting and transporting which is considered more effective for combine 3 . However, the lowest 
header losses for combine 1, 2, 3 and mower were 2.84, 1.93, 0.64 and $1.03 \%$ respectively at forward speed $1.9 \mathrm{~km} / \mathrm{h}$ and grain moisture content $16.58 \%$.

\section{Drum, straw walker and cleaning losses for combine harvester:}

The performance parameters of drum, straw walker and cleaning units are the percentage of detached and the percent of damaged seeds from threshing unit and separate the threshed seeds from straw (straw walker effectiveness) then to separate seeds from the chaff and other plant residues that have passed through the openings.

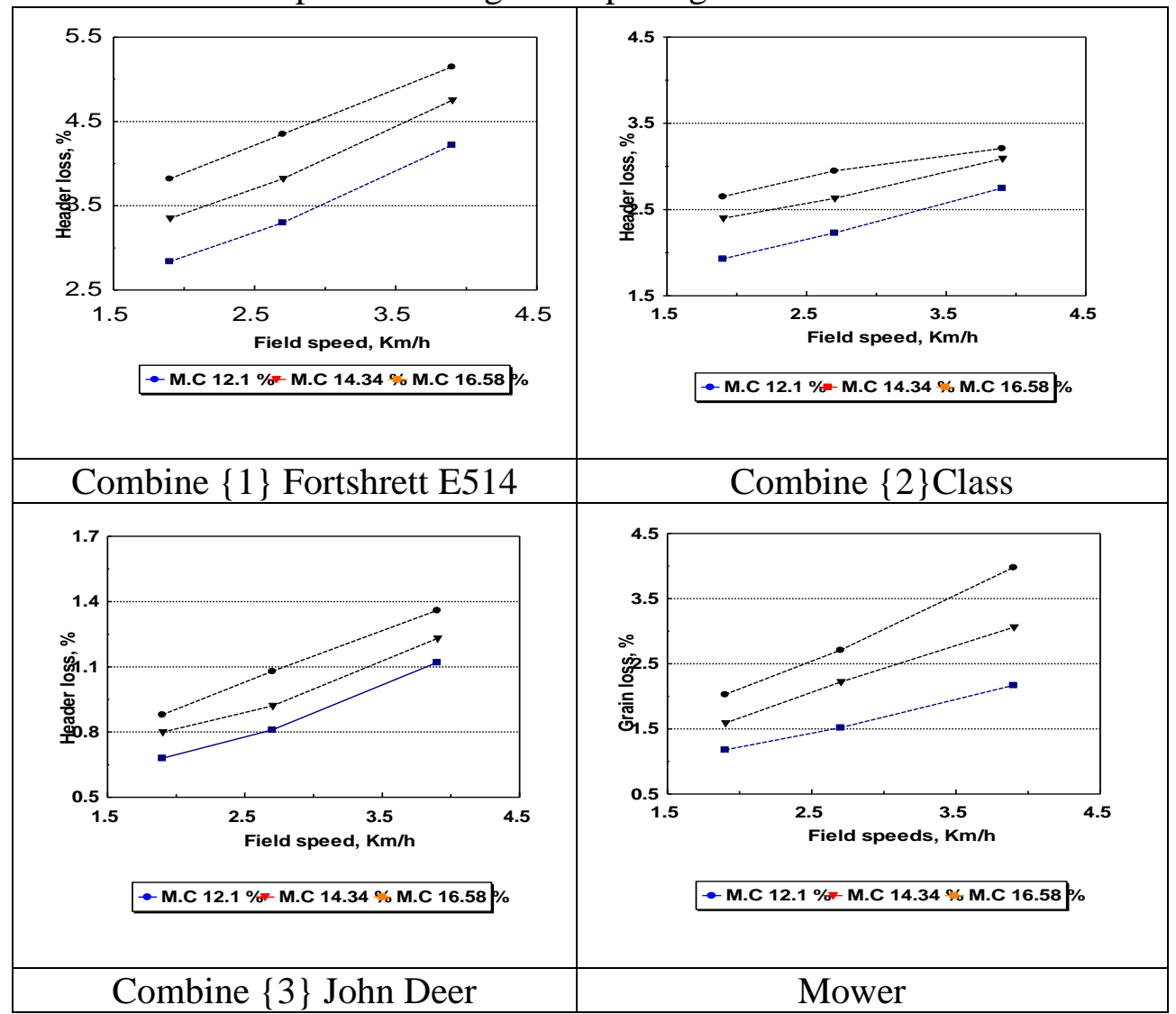

Fig. 1. Combine header and mower losses as affected by field speeds and grain moisture contents

Fig (2). showed that increasing harvesting speed increased grain losses. The highest drum, straw walker and shoe grain losses for combine 1, 2 and 3 were $5.21,3.98$ and $1.36 \%$ respectively at forward speed $3.9 \mathrm{~km} / \mathrm{h}$ 
and moisture content $12.1 \%$ while the lowest drum, straw walker and cleaning grain losses for combine 1, 2 and 3 were 3.35, 2.27 and $0.74 \%$ respectively at forward speed $1.9 \mathrm{~km} / \mathrm{h}$ and moisture content $16.58 \%$.

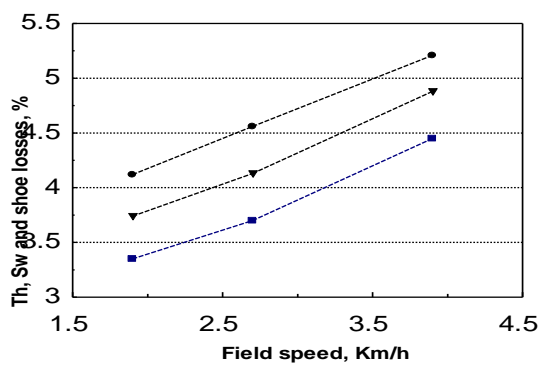

$\rightarrow$ M.C $12.1 \%$ M.C $14.34 \%$ M.C $16.58 \%$

Combine $\{1\}$ Fortshrett E514

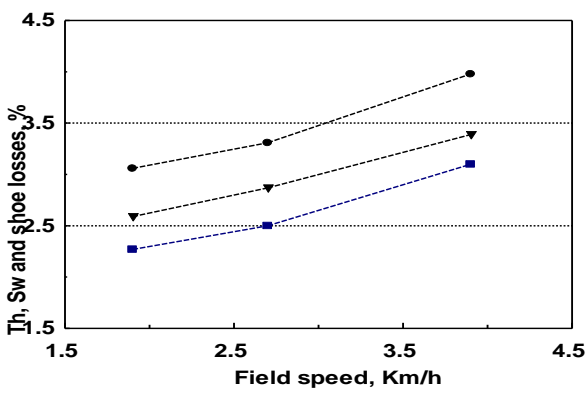

$\bullet-$ M.C $12.1 \%$ M.C $14.34 \%$ M.C $16.58 \%$

Combine $\{2\}$ Class

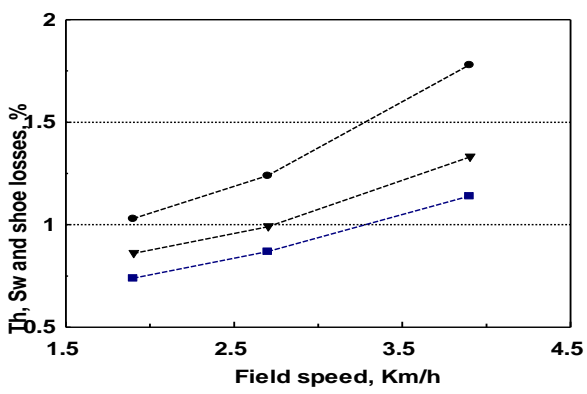

$\rightarrow$ M.C $12.1 \%$ M.C $14.34 \%$ M.C $16.58 \%$

Combine $\{3\}$ John Deer

Fig. 2. Drum, straw walker and shoe losses as affected by field speeds, wheat variety and grain moisture contents 


\section{Total grain losses for combine harvesters}

Fig. (3) shows that total grain losses were increased with increasing field speeds and decreasing moisture contents. The highest total grain losses for combine 1, 2 and 3 were $10.36,7.19$ and $3.14 \%$ respectively at forward speed $3.9 \mathrm{~km} / \mathrm{h}$ and moisture content $12.1 \%$ while, the lowest total grain losses for combine 1, 2 and 3 were $6.19,4.2$ and $1.42 \%$ respectively at forward speed $1.9 \mathrm{~km} / \mathrm{h}$ and moisture content $16.58 \%$. The polynomial equation form was used and $\mathrm{R}^{2}$ was not less than 0.98 .

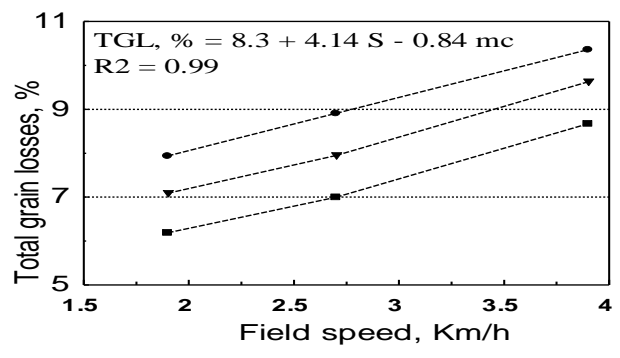

-M.C $12.1 \%$ M.C 14.34\%M.C $16.58 \%$

Combine $\{1\}$ Fortshrett E514

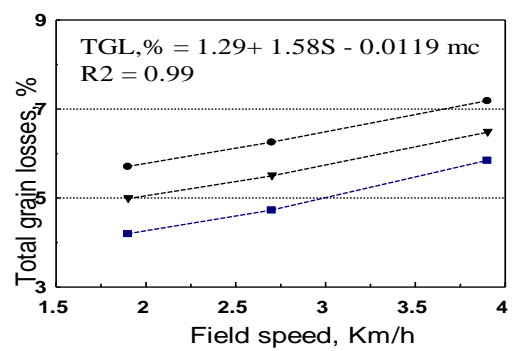

- M.C 12.1 \% M.C 14.34-\$M.C 16.58\%,

Combine $\{2\}$ Class

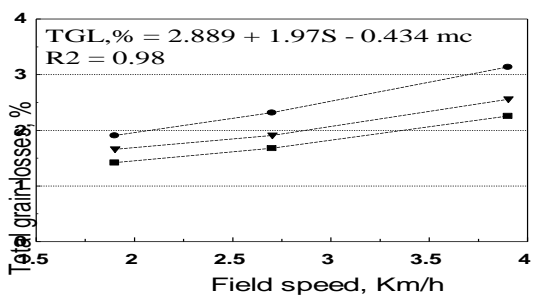

- M.C 12.1-961.C 14.34N\%O 16.58\%

Combine $\{3\}$ John Deer

Fig.3. Total grain losses as affected by field speeds and grain moisture contents 
Fig. (4) shows that total grain losses was affected by different moisture contents with the three combines at forward speed $2.7 \mathrm{~km} / \mathrm{h}$ which gave the least energy.

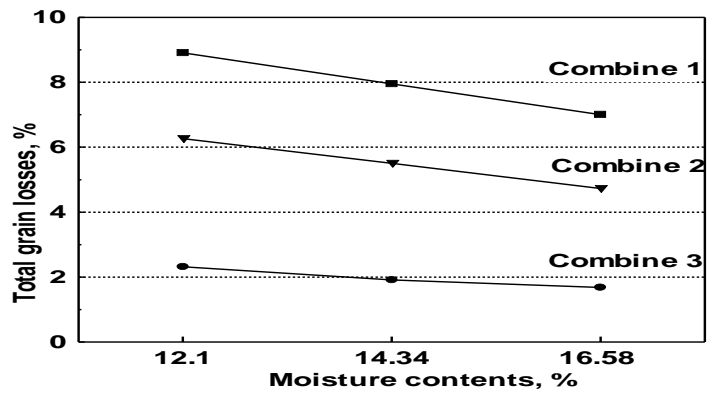

Fig. 4. Total grain losses as affected by different moisture contents at forward speed $2.7 \mathrm{~km} / \mathrm{h}$ which gave the least energy.

Effect of threshing drum design and grain moisture contents on unthreshing losses and grain damage:

Table 5. Illustrated that the highest un-threshing losses were 1.13 and $1.42 \%$ for thresher 1 and 2 respectively at moisture content $16.58 \%$ while, the highest grain damage were 2.24 and $2.02 \%$ for thresher 1 and 2 respectively at moisture content $12.1 \%$. Un-threshing losses increased about $0.13 \%$ when using thresher 2 compared to thresher 1 . However, grain damage decreased about $0.22 \%$ when using thresher 2 compared to thresher 1.

Table5.Grain damaged and un-threshed grains as affected by drum geometrical design, grain moisture content and crop varieties at feed rate one $\mathrm{Mg} / \mathrm{h}$.

\begin{tabular}{|c|c|c|c|c|}
\hline \multirow{2}{*}{$\begin{array}{c}\text { Grain } \\
\text { moisture } \\
\text { contents, \% }\end{array}$} & \multicolumn{2}{|c|}{ Thresher 1} & \multicolumn{2}{|c|}{ Thresher 2} \\
\hline & $\begin{array}{l}\text { Un-threshing } \\
\text { loss, } \%\end{array}$ & $\begin{array}{c}\text { Grain } \\
\text { damaged, } \%\end{array}$ & $\begin{array}{l}\text { Un-threshing } \\
\text { loss, } \%\end{array}$ & $\begin{array}{c}\text { Grain damaged, } \\
\%\end{array}$ \\
\hline 12.1 & 0.63 & 2.24 & 0.76 & 2.02 \\
\hline 14.34 & 0.86 & 1.73 & 1.03 & 1.46 \\
\hline 16.58 & 1.13 & 1.45 & 1.22 & 1.28 \\
\hline
\end{tabular}

\section{Actual field capacity and field efficiency:}

Although the field capacity increased, the field efficiency decreased with the increase of harvesting speed. The actual field capacity was low under manual harvesting (one labor can harvest $0.025 \mathrm{fed} . / \mathrm{h}$ ) that due to low 
human energy. Fig. (5). Showed that the highest actual field capacity for combine 1, 2, 3 and mower were 2,08, 1.66, 2.68 and $0.68 \mathrm{fed} / \mathrm{h}$ respectively at field speed $3.9 \mathrm{~km} / \mathrm{h}$ while, the highest field efficiency for combine 1, 2, 3 and mower were 72.73, 78.14, 66.37 and $88.74 \%$ respectively at field speed $1.9 \mathrm{~km} / \mathrm{h}$. Moussa 1994 indicated that field capacity increased from 1.57 to $2.17 \mathrm{fed} / \mathrm{h}$ by increasing field speed from 2.5 to $4.4 \mathrm{~km} / \mathrm{h}$ while, field effieciency decreased from 72 to $58 \%$ by increasing field speed from 2.5 to $4.4 \mathrm{~km} / \mathrm{h}$.

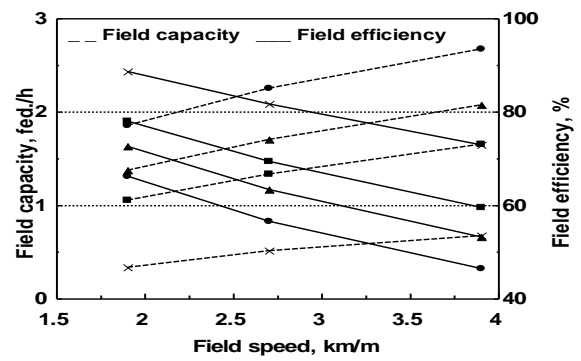

-- Fort -- class-๑- John-x-Mowgr

Fig. 5. Field capacity and field efficiency for Combines 1, 2, 3 and mower as affected by field speeds and cutting width

\section{Energy requirements:}

Energy was calculated and tabulated in table 6. It is clear that harvesting speed $2.7 \mathrm{~km} / \mathrm{h}$ gave the lowest energy with combine 1,2 and 3 which were $38.95,34.76$ and $43.61 \mathrm{~kW} . \mathrm{h} /$ fed respectively.

Mechanical method (mower then thresher) consumed about double energy consumed by combine method; while, traditional method (sickle then thresher) consume about the same energy with combine.

\section{Harvesting cost:}

The total harvesting cost is affected by the harvesting speed. Total grain losses cost increased by increasing harvesting speeds in case of using combines and mower.

Table7. shows that the highest criterion cost with combine1, 2, 3 and mower are 255.9, 277.59, 177.56 and 158.06 LE/fed respectively at field speed $3.9 \mathrm{~km} / \mathrm{h}$, and grain moisture content $12.1 \%$; while the lowest criterion cost with combine1, 2, 3 and mower are 252.89, 203.74, 135.07 and $89.15 \mathrm{LE} / \mathrm{fed}$ at field speed $1.9 \mathrm{~km} / \mathrm{h}$, and grain moisture content $16.58 \%$. 
Table 6. Energy requirements as affected by field speeds and machines

\begin{tabular}{|l|c|c|c|c|}
\hline Machines & $\begin{array}{c}\text { Speed, } \\
\mathrm{km} / \mathrm{h}\end{array}$ & $\begin{array}{c}\text { Power, } \\
\mathrm{kW}\end{array}$ & $\begin{array}{c}\text { Actual field } \\
\text { capacity, fed./h or } \\
\text { feed rate, } \mathrm{Mg} / \mathrm{h} .\end{array}$ & $\begin{array}{c}\text { Energy, } \\
\mathrm{kW} . \mathrm{h} / \mathrm{fed} .\end{array}$ \\
\hline \multirow{5}{*}{ Combine 1 } & 1.9 & 56.91 & 1.38 & 41.24 \\
\cline { 2 - 5 } & 2.7 & 66.60 & 1.71 & 38.95 \\
\cline { 2 - 5 } & 3.9 & 85.46 & 2.08 & 41.09 \\
\hline \multirow{5}{*}{ Combine 2 } & 1.9 & 40.64 & 1.06 & 38.34 \\
\cline { 2 - 5 } & 2.7 & 46.58 & 1.34 & 34.76 \\
\cline { 2 - 5 } & 3.9 & 61.04 & 1.66 & 36.77 \\
\hline \multirow{3}{*}{ Combine 3 } & 1.9 & 84.03 & 1.86 & 45.18 \\
\cline { 2 - 5 } & 2.7 & 95.92 & 2.26 & 43.61 \\
\cline { 2 - 5 } & 3.9 & 126.17 & 2.68 & 47.08 \\
\cline { 2 - 5 } & 1.9 & 16.05 & 0.34 & 47.20 \\
\cline { 2 - 5 } & 2.7 & 23.16 & 0.52 & 44.54 \\
\hline Manual & 3.9 & 33.11 & 0.68 & 2.98 \\
\hline Thresher 1 & - & 0.373 & 0.025 & 34.62 \\
\hline Thresher 2 & - & 34.62 & $1.0 \mathrm{Mg} / \mathrm{h}$. & 31.76 \\
\hline
\end{tabular}

Fig. 6. shows that criterion cost was affected by different combines at forward speed $2.7 \mathrm{~km} / \mathrm{h}$ and moisture content $16.58 \%$ (which gave the least energy and criterion cost).

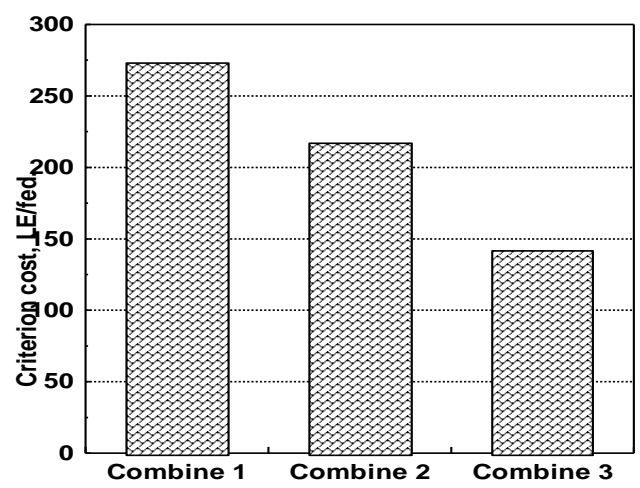

Fig.6. Criterion cost as affected by different combines at forward speed $2.7 \mathrm{~km} / \mathrm{h}$ and moisture content $16.58 \%$ (which gave the least energy and criterion cost). 
Table 7. Criterion cost and grain losses costs for combines and mower at different moisture contents and field speeds

\begin{tabular}{|c|c|c|c|c|c|c|c|}
\hline \multirow[b]{2}{*}{ Machines } & \multirow[b]{2}{*}{$\begin{array}{l}\text { Field } \\
\text { speed, } \\
\mathrm{km} / \mathrm{h} .\end{array}$} & \multicolumn{2}{|c|}{$12.1, \%$} & \multicolumn{2}{|c|}{$14.34, \%$} & \multicolumn{2}{|c|}{$16.58, \%$} \\
\hline & & $\begin{array}{c}\text { Grain } \\
\text { loss cost, } \\
\text { LE/fed. }\end{array}$ & $\begin{array}{c}\text { Criterion } \\
\text { cost, } \\
\text { LE/fed. }\end{array}$ & $\begin{array}{l}\text { Grain loss } \\
\text { cost, } \\
\text { LE/fed. }\end{array}$ & $\begin{array}{c}\text { Criterion } \\
\text { cost, LE/fed. }\end{array}$ & $\begin{array}{c}\text { Grain } \\
\text { loss cost, } \\
\text { LE/fed. }\end{array}$ & $\begin{array}{l}\text { Criterion } \\
\text { cost, } \\
\text { LE/fed. }\end{array}$ \\
\hline \multirow{3}{*}{ Combine 1} & 1.9 & 196.1 & 296.1 & 175.12 & 275.12 & 152.89 & 252.89 \\
\hline & 2.7 & 240.6 & 340.6 & 196.37 & 296.37 & 172.9 & 272.9 \\
\hline & 3.9 & 255.9 & 355.9 & 237.86 & 337.86 & 214.15 & 314.15 \\
\hline \multirow{3}{*}{ Combine2 } & 1.9 & 141.04 & 241.04 & 123.25 & 223.25 & 103.74 & 203.74 \\
\hline & 2.7 & 154.62 & 254.62 & 135.85 & 235.85 & 116.83 & 216.83 \\
\hline & 3.9 & 177.59 & 277.59 & 160.06 & 260.06 & 144.5 & 244.5 \\
\hline \multirow{3}{*}{ Combine 3} & 1.9 & 47.18 & 147.18 & 41 & 141 & 35.07 & 135.07 \\
\hline & 2.7 & 57.3 & 157.3 & 47.18 & 147.18 & 41.5 & 141.5 \\
\hline & 3.9 & 77.56 & 177.56 & 63.23 & 163.23 & 55.82 & 155.82 \\
\hline \multirow{3}{*}{ Mower } & 1.9 & 50.14 & 110.1 & 39.27 & 99.27 & 29.15 & 89.15 \\
\hline & 2.7 & 66.94 & 126.94 & 54.83 & 114.83 & 37.54 & 97.54 \\
\hline & 3.9 & 98.06 & 158.06 & 75.58 & 135.58 & 53.6 & 113.6 \\
\hline
\end{tabular}

*Combine cost was 100 L.E./fed. *Mower cost was 60 L.E./fed.

The highest criterion cost with sickle is $229.65 \mathrm{LE} / \mathrm{fed}$ at grain moisture content $12.1 \%$ while the lowest criterion cost is $212.85 \mathrm{LE} / \mathrm{fed}$ at moisture content $16.58 \%$. The highest criterion cost with thresher 1 and 2 are 225.89 and $223.67 \mathrm{LE} /$ fed respectively at grain moisture content 12.1 $\%$; while, the lowest criterion cost with thresher 1 and 2 are 218.73 and 216.75 LE/fed respectively at grain moisture content $16.58 \%$. see Table 8.

Table 8. Operating and losses costs for threshers and manual harvesting

\begin{tabular}{|l|c|c|c|c|c|c|}
\hline \multirow{2}{*}{ Machine } & \multicolumn{2}{|c|}{$12.1, \%$} & \multicolumn{2}{c|}{$14.34, \%$} & \multicolumn{2}{c|}{$16.58, \%$} \\
\cline { 2 - 7 } & $\begin{array}{c}\text { Grain loss } \\
\text { cost, LE/fed.cost, LE/fed. }\end{array}$ & $\begin{array}{c}\text { Criterion loss } \\
\text { cost, LE/fed. }\end{array}$ & $\begin{array}{c}\text { Criterion } \\
\text { cost, LE/fed. }\end{array}$ & $\begin{array}{c}\text { Grain loss } \\
\text { cost, LE/fed. }\end{array}$ & $\begin{array}{c}\text { Criterion } \\
\text { cost, LE/fed. }\end{array}$ \\
\hline Sickle & 49.65 & 229.65 & 41.25 & 221.25 & 32.85 & 212.85 \\
\hline Thresher 1 & 70.89 & 225.89 & 63.97 & 218.97 & 63.73 & 218.73 \\
\hline Thresher 2 & 68.67 & 223.67 & 61.50 & 216.5 & 61.75 & 216.75 \\
\hline
\end{tabular}

*Thresher cost was 25 L.E./h * 8-labour for feeding machine/day

* Labor salary/day is 20 L.E

Combine reduced the criterion cost of harvesting about 32 and $36 \%$ compared with semi mechanical system (mower + transportation + thresher) and traditional system (manual + transportation + thresher) respectively. 


\section{CONCLUSION}

From the previous study it may say that:

* The highest harvesting loss for sickle and mower are 2.01 and $3.98 \%$ respectively at grain moisture content $12.1 \%$ and field speed $3.9 \mathrm{~km} / \mathrm{h}$ (for mower).

* The highest header losses for combine 1, 2 and 3 were, 5.15, 3.27 and $1.19 \%$ respectively at forward speed $3.9 \mathrm{~km} / \mathrm{h}$ and grain moisture content $12.1 \%$.

* The highest drum, straw walker and shoe grain losses for combine 1, combine 2 and combine 3 were 5.21, 3.98 and $1.76 \%$ respectively at forward speed $3.9 \mathrm{~km} / \mathrm{h}$ and moisture content $12.1 \%$

* The shorter service life for combine the less total grain losses.

* the highest un-threshing losses were 1.13 and $1.22 \%$ for thresher 1 and 2 respectively at moisture content $16.58 \%$ while, the highest grain damage were 2.24 and $2.02 \%$ for thresher 1 and 2 respectively at moisture content $12.1 \%$.

* Un-threshing losses increased about $33 \%$ when using thresher 1 compared to thresher 2. However, grain damage decreased about $13 \%$ when using thresher 2 compared to thresher 1 .

* the highest actual field capacity for combine 1,2, 3 and mower were 2,08, 1.66, 2.68 and $0.68 \mathrm{fed} / \mathrm{h}$ respectively at field speed $3.9 \mathrm{~km} / \mathrm{h}$ while, the highest field efficiency for combine 1, 2, 3 and mower were 72.73, $78.14,66.37$ and $88.74 \%$ respectively at field speed $1.9 \mathrm{~km} / \mathrm{h}$.

* harvesting speed $2.7 \mathrm{~km} / \mathrm{h}$ gave the lowest energy with combine 1,2 and 3 which were $38.95,34.76$ and $43.61 \mathrm{~kW} . \mathrm{h} /$ fed respectively.

* The highest criterion cost with sickle is $229.65 \mathrm{LE} /$ fed at grain moisture content $12.1 \%$

* The highest criterion cost with thresher1 and 2 are 225.89 and 223.67 LE/fed respectively at grain moisture content $12.1 \%$.

\section{REFERENCES}

Abd El-Mawla, H. A. 1996. Combine harvesting state of Art. Misr. J. Agric. Eng., 13 (2): 440 - 459.

Awady, M. N.; Ghoniem, E. Y. and Hashish, A. I. 1982. A critical comparison between wheat combine harvesters under Egyptian condition, Ain-Shams Univ. Cal. Ag. Res. Bul. No. 1920: 13 p.

ASAE Standards. 1996 ASAE S495, EP 496.2 and D497.. Agricultural 
machinery management data. ASAE, St. Joseph, MI

Chancellor, W. J. 1981. Substituting information for energy in agriculture. Transaction ASAE, (5): 802-807.

Embaby, A. T. 1985. A comparison of the different mechanization systems for cereal crop production. M. Sc. Thesis Agric. Eng., Fac. Of Agric., Cairo Univ.

Hassen. M. A.; M. M. Morad; M. A. El Shazly and A. Farage. 1994. Study on some operating parameters affecting the performance of combine devices with reference to grain losses. Misr J. of Agri. Eng. Vol. 11 (3): 764-780.

Issakhan, M.I; F.M. Arjan; S. Hussain and M.T. Tnrig. 2005. Effect of soy flour supplementation on mineral and phytate contents of unleavened flat bread. Nutrition Food Science, 163-168.

Kassem. A. S. 1995. Effects of some crop and machine parameters on wheat and barely harvesting losses in Saudi Arabia. Misr J. of Agri. Eng. Vol. 12 (4): 866-880.

Moussa, A. I. 1994. Design, construction and testing of a straw cutting and compressing device integrated within a combine. Ph.D thesis Zagazig Univeresity.

Wang, G.; C. Zoerb and L. G. Hill 1988. A combine separation loss monitor. Trans. of The ASAE, 31 (2): 692 - 694.

\section{الملخص العربي (2) - 2 المب}

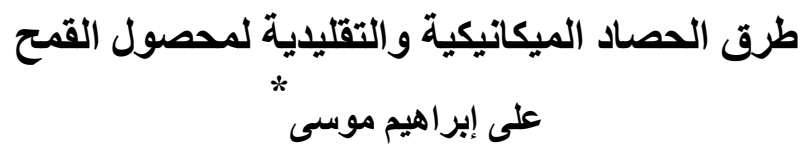

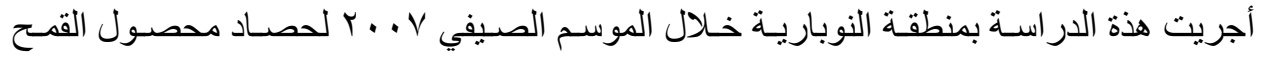

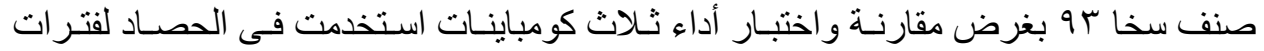

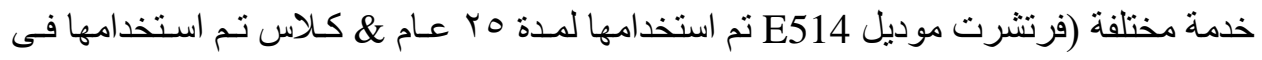

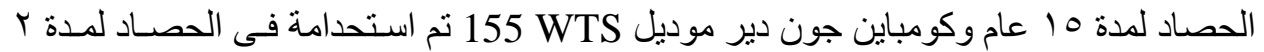

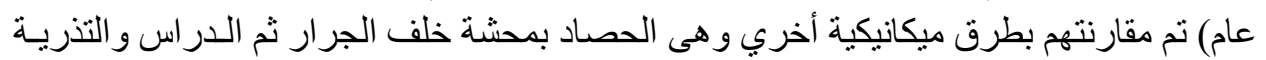

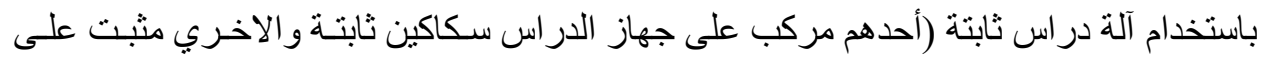

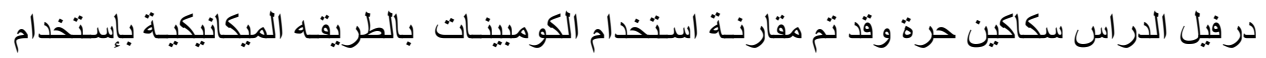

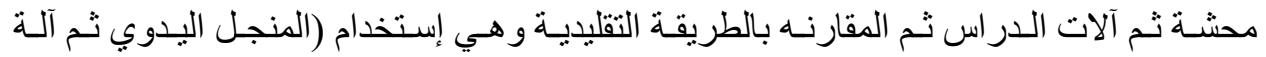

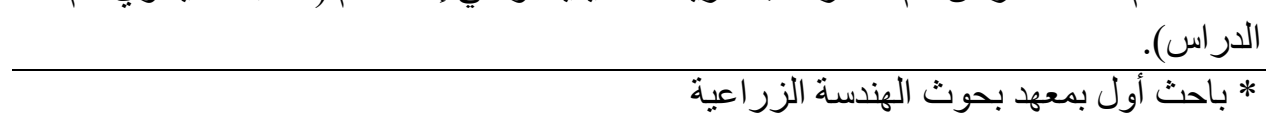




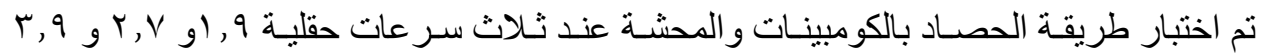

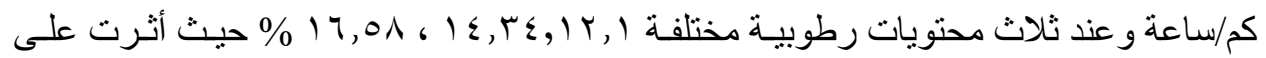

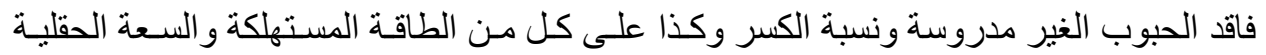

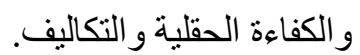
وقد أوضحت النتائج مايلى:

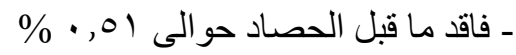

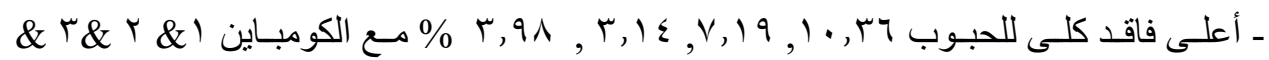

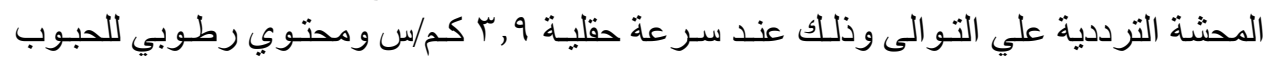

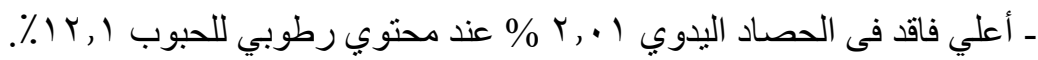

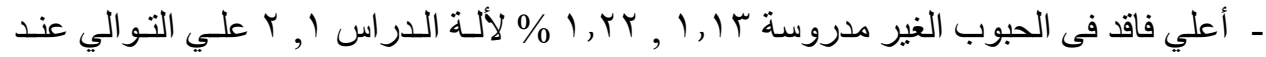

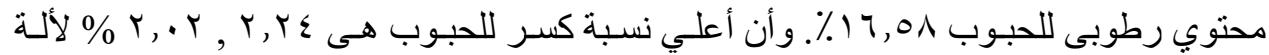

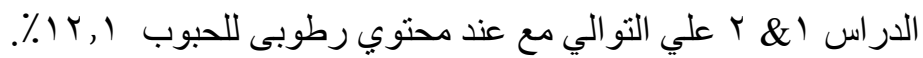

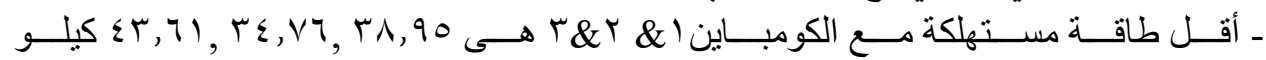

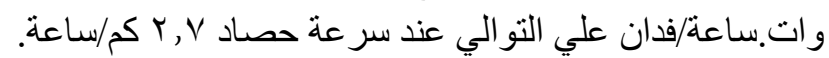

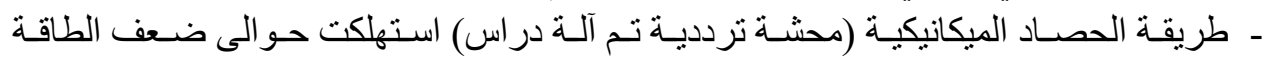
المستهلكة فى حالة الكو مباين. ـ طريقـة الحصـاد التقليديـة (محشـة يدويـة تـم آلـة در اس) اسـتهلكت حـو الى نفس كميـة الطاقـة المستهلكة فى حالة الكومباين. ـ أعلي تكلفة فى الحصاد بالكو مباين ال

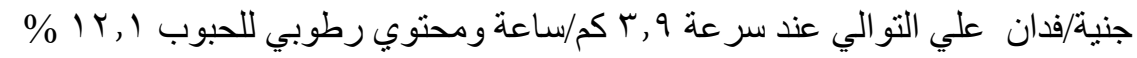

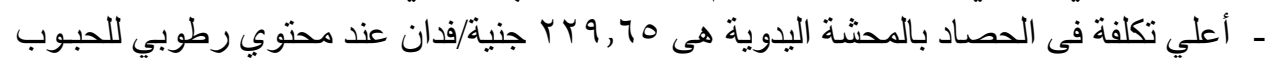
$\% \mid r, 1$

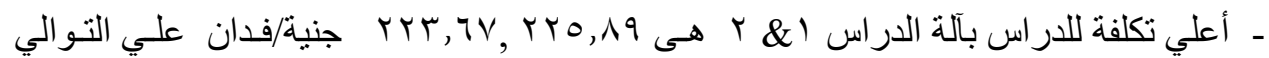
عند محتوي رطوبي للحبوب ا, إ) 